\title{
JACOPO ANTONIO MARCELLO HOLDSARLÓ- ÉS SÁRKÁNYRENDJE
}

Luxemburgi Zsigmond király és császár emlékét 1987-ben és 2006-ban is gazdag kiállítás ünnepelte. A katalógusokat kísérő tanulmányok mindkét alkalommal foglalkoztak a magyar király alapította Sárkányrenddel. Kovács Éva, korábbi kutatásaira is támaszkodva, a korabeli rendekkel összefüggésben vizsgálta az írásos és tárgyi emlékeket. ${ }^{1}$ Lővei Pál a kitüntetettek föllelhető névsorát gyüjtötte össze. Újabb tanulmányában az uralkodói lovagrendek szélesebb összefüggésébe helyezte a jórészt maga föltárta tárgyi emlékeket. ${ }^{2} \mathrm{E}$ tanulmányok ismerete tette lehetővé, hogy fölfigyeljek egy írott forrásra, amelyben egy, az ezekkel a rendjelekkel kitüntetett újabb személyt azonosíthatunk.

Janus Pannonius monumentális, majdnem 3000 soros dicsőitő éneket írt pártfogójáról, Jacopo Antonio Marcello velencei patríciusról 1455-58-ban. ${ }^{3}$ Kettejük kapcsolata jól ismert, és még Janus ferrarai tanulmányainak idejére vezethető vissza. Valamikor 1450 után szerezhetett tudomást Marcello Gaurino verselő készségü tanítványáról. Ez akkor történt, amikor a megfelelő formába öntött szavaknak akár politikai hatóeröt is tulajdonítottak. Az írástudók meg nagyon is meg voltak győződve arról, hogy a tárgyalt vagy a megverselt eseményeket, a hős ismertségét és nevének fönnmaradását csak az ő közreműködésük biztosítja. Pártfogó és pártfogolt viszonya egymásra utalt volt, még akkor is, ha

1 KovÁcs Éva, A Luxemburgi-uralkodók rendjei = Müvészet Zsigmond király korában, 1387 1437, I-II, szerk. BeKe László, Marosi Ernő, Wehli Tünde, Bp., Budapesti Történeti Múzeum, 1987, I, 135-147.

2 LÖVEI Pál, Uralkodói lovagrendek a középkorban, különös tekintettel Zsigmond Sárkányrendjére = Sigismundus rex et imperator: Müvészet és kultúra Luxemburgi Zsigmond korában, 1387-1437, szerk. TAKÁCS Imre, Bp.-Luxemburg, Szépművészeti Múzeum-Musée National d'Histoire et d'Art, Luxemburg, 2006, 251-263; Uö, A Sárkányrend fennmaradt emlékei = Müvészet Zsigmond király korában ..., i. m., I, 148-179;

3 Panegyricus ad Iacobum Marcellum Venetum = JANUS, Poemata. 
az utóbbi ellenszolgáltatást várt múvéért. Janus esetében ez a kölcsönös kapcsolat Marcellóval 1452-töl ismert. A belháborúktól gyötört Itália - különös módon - már csak a kívülről jövő segítségben reménykedett. Frigyes német király 1452 januárjában lépett Itália földjére azzal a céllal, hogy Rómában a pápa német-római császárrá koronázza. Fölszabadítóként, béketeremtőként ünnepelték városrólvárosra, amint haladt dél felé. Ebbe az ünneplő koncertbe kapcsolódott bele a 18 éves Janus Pannonius verse is Ferrarában: a Pro pacanda Italia ad Imp. Caes. Fridericum, amelyet Marcello kívánságára írt. ${ }^{4}$ Ezt még ugyanebben az évben egy terjedelmes mü követte, az ugyancsak Marcello megbízásából született René, nápolyi trónkövetelő korábbi viszontagságos uralmának története. ${ }^{5}$

Janus tanulmányait 1455-tôl a padovai jogi egyetemen folytatta. A város a Velencei Köztársaság fönnhatósága alatt állt. Ezután már rendszeres kapcsolatban volt Janus korábbi pártfogójával, Marcellóval. Bejáratos volt a velencei palotába és a patrícius monselicei otthonába is. ${ }^{6}$ Csak így magyarázható, hogy honnan származhattak részletekre kiterjedően pontos ismeretei Marcello évtizedekkel korábbi cselekedeteiről is. Erről a padovai évekről írt, már említett, monumentális dicsőítő műve tanúskodik, amelyet korábbi támogatójára, vagy inkább támogatójának alkotott. Hősét családja körében ifjú korától mutatja be, majd rátér hadi tetteire. Ezekre Velence Milánó ellen viselt hosszú háborúja során került sor. Marcello ugyanis a fölfogadott, általában idegen származású hadvezérek mellett a valóban velencei hadbiztos (provisor, provveditore) volt. $^{7}$ Janus elbeszélése szerint Marcello a hadi vállalkozások során a leleményesség és személyes bátorság annyi jelét tanúsította, hogy a katonák tanúsága szerint is megérdemelten lett a lovagrend tagja és kapta a „militiae auratae” kitüntetést. Itt tér rá Janus arra, hogy a hazai elismerések mellett Marcello külföldi uralkodóktól is kapott érdemrendeket:

\section{Multa huic diversi tribuere insignia reges sponte sua; in primis modo Parthenopaea Renatus sceptra tenens; post hunc Francorum summa potestas.}

4 Uo., 211-231.

5 De laudibus Renati Siciliae regis libri tres. Cím nélküli változatának felét egy vatikáni kódexből kiadta ÁBEL Jenő, Analecta, 131-144. A teljes szövegnek újkori másolatát megtalálta és kiadta Szentmártoni Szabó Géza, Parthenope veszedelme: Újdonságok a Janus Pannonius-filológia köréböl, Bp., 2010, 33-93. A koráig rendelkezésére álló források alapján a kérdést tárgyalta Huszti József, Janus Pannonius és Anjou René, Bp., 1929 (Minerva Könyvtár, 23.), ill. Uö, Janus Pannonius, Pécs, 1931.

6 RitoóKné Szalay Ágnes, Andrea Mantegna és Janus Pannonius, Művészettörténeti Értesítő, LVIII(2009), 1-16. A jelen kötetben: 70-92.

7 Margaret L. KING, The Death of the Child Valerio Marcello, Chicago-London, 1994, 240-312. A kronológia Marcello életét forrásokra támaszkodva követi. 
Quin et Pannoniae rector, tua cura, superbae, nobile nuper ei veterum gestamen avorum contulit adveniens, unde illi in pectore laevo ignea gemmati dependet spira draconis. ${ }^{8}$

Prózai fordításban: „Önként adott neki több király sok kitüntetést. Elsőként, csak most, Renatus, Nápoly uralkodója, ezután a frankok főhatalmassága. Sőt még a büszke Pannonia uralkodója is, akire neked gondod volt, megérkezve őseinek nemes viselményét adta neki, ezért függ bal mellén az ékköves sárkány tüzvörös tekervénye."

Az elsőként említett Renatus a Nápolyt és Szicíliát rövid ideig birtokló René d'Anjou. Viszontagságos hatalomra jutását és néhány éves uralkodását, majd elüzettetését íratta meg Janusszal 1452-ben Marcello. A továbbra is magát trónkövetelőnek tekintő René és a velencei patrícius addig sohasem találkoztak. Kapcsolatuk létrehozója Francesco Sforza volt, aki egy időben - nem is rövid ideig - Velence oldalán volt a Milánó elleni háborúkban. Sforza apja nápolyi szolgálatban állt egykor, és ő maga is kitartott René érdekeinek védelmezésében. Ezt ismerte el René akkor, amikor 1448-ban egy új lovagrendet alapított Angers-ben. Az első fölveendők között volt 1449-ben Sforza és Marcello is. Az új rend neve Ordre de la Croissant, magyarra fordítva Félhold- (Lővei Pál szerint) vagy Holdsarlórend. ${ }^{9}$ A fönnmaradt statútumok és tárgyi emlékek alapján jó ismereteink vannak a társaságról. Társaságnak azért lehet nevezni, mert az alapító szándéka szerint nem volt monarchikus a rend. Tagjai vele együtt egyenrangúak voltak, valamennyiük praesese és patrónusa Szent Móric. A rend jelvénye a jobb kar alá illesztett, mintegy harminc centiméteres, nyílvánvalóan textíliából készített holdsarló volt. Évenként a védőszent ünnepén, szeptemberben jöttek össze az angers-i székesegyház kápolnájában. Itt tartozott minden tag megjelenni, vagy magát írásban (!) kimenteni. Ekkor került sor az új tagok fölvételére és az eskütételre. Ekkor választották maguk közül egy évre a senatort, aki az adminisztrációs ügyeket fölügyelte. A tagok kötelességei nagyjából megegyeztek az Aranygyapjas rendet viselőkével, az Egyház és egymás iránti szabályokat illetően. A továbbiak szempontjából különösen érdekes, hogy csak az igazságos háború esetén foghattak fegyvert, és csak uruk mellett harcolhattak. A rend statútumainak ismertetője, Darcy J. D. Boulton figyelmeztet arra, hogy ezekben sokhelyütt fölfedezhetők az ,arturi lovagvilág” nyo-

8 Panegyricus ad... Marcellum, i. m., 1644-1650.

9 KING, i. m., 272. 
mai. ${ }^{10}$ Ezen nem is csodálkozhatunk, mert René udvara, és ő maga is a középkori lovagvilág megörzője volt.

Marcello esetében a rend iránti kötelességek teljesítése mindjárt az elején nehézségekbe ütközött. A Velencei Köztársaság hadseregének provisoraként nem hagyhatta el állomáshelyét. A Milánóval viselt háború eseményei nem igazodtak a Holdsarlórend patrónusának évi ünnepéhez. Marcello így 1449-50-ben nem lehetett ott az évi közgyülésen, hogy a statútumokra esküt tegyen, és ezzel formálisan is fölvételt nyerjen a rendbe. Ezt 1449 decemberében egy igazán lovagias gesztussal megelőlegezte. René feleségének, Izabellának egy Michelino da Besozzo készítette kártyasorozatot küldött, amit ő korábban Filippo Maria Viscontitól (†1447) kapott. A kártya ma már nincs meg, de a kísérő szép kis pergamenkódex igen, és ebböl tudjuk, hogy a lapokon allegorikus alakok jelenítették meg az erényeket és a bünöket. Marcello ajánlólevelét 1449. december 12-én keltezte monselicei birtokáról, ahová a tél beálltával megszünt hadakozás miatt vonulhatott vissza. ${ }^{11}$ A találkozásra a következö években sem került sor. 1452 áprilisában újabb könyvajándékot küldött Renének. Az ajánlólevél szerint föltett szándékának most sem tehet eleget. A kötelezettségének (,officio debito”!) és vágya teljesítésének most is, az idők viszontagságai miatt, a Köztársaság az akadályozója. ${ }^{12}$ Ekkor adhatta a megbízást Janusnak, hogy René ifjúságáról és rövid nápolyi királyságáról egy hosszabb müvet alkosson. Marcello sem, Janus sem ismerte Renét. A jóval korábban, 1442-ig történt eseményekről a költőnek nem sok ismerete volt. Kitöltötte ezért a hiányt a római történelem, a hadtudomány és általában tanulmányai során az ókori irodalmakból összegyüjtött elemekkel. Janus Renéhez szóló ajánlásából derül ki a mü célja, amely nyilván Marcello utasítását követte. Ez pedig úgy szólt, hogy René keljen át az Alpokon birodalmának fegyverrel való visszaszerzésére. ${ }^{13}$ Huszti József szerint Janus verse a restaurációs kísérlet

${ }^{10}$ D'Arcy Jonathan Dacre Boulton, The Knights of the Crown: The Monarchial Orders of Knighthood in Later Medieval Europe, 1325-1520, The Boydell Press, 2000, 611-622. A könyv ismeretét Lővei Pálnak köszönöm.

${ }^{11}$ Paris, Bibliothèque National, ms. lat. 8745. Splendeur de l'enluminure. Le roi René et les livres, sous la direction de Marc-Edouard GAUTIER avec les conseils scientifiques de François AVRIL, Exposition Ville d'Angers 3 octobre-3 janvier 2010, Ville d'Angers-Actes Sud, 2010, No. 43, 348. (Anne-Marie LEGARÉ) Szentmártoni Szabó Géza példányát használhattam. A kódex másolója és díszítője Michele Salvatico. Elisabetta BARILE, Littera antiqua e scrittura alla greca: Notai e cancellieri copisti a Venezia nei primi decenni del Quattrocento, Venezia, 1994, 129.

12 De sacerdotio Jesu Christi, trad. Lauro Quirini, Roma, Biblioteca Nazionale, Cod. Corsin. 839 (43 D 8), f. 78r alapján közli az ajánlás szövegét Giovanni Mercati, Sull'opuscolo, De sacerdotio Christi attribuito al Traversari = Giovanni MERCATI, Ultimi contributi alla storia degli umanisti, I, Città del Vaticano, 1939 (Studi e Testi, 90), 81. A görög szöveget is tartalmazza.

13 „Quare age, nubiferas transcende ferociter Alpes,

Causa tibi faciles suggeret aequa deos."

De laudibus Renati..., i. m., 11-12. 
bevezető propagandairata volt. A mü végül is 1452 végére elkészült, és föltételezésünk szerint el is jutott a megajándékozandóhoz. Erre abból következtethetünk, hogy Marcello most a francia oldalról tapasztalhatott jóindulatot. Valamikor, még 1453 előtt Giovani Cossa, René leghüségesebb nápolyi követője (,fidèle d'entre les fidèles") eljuttatta, de nem lehetetlen, hogy személyesen átadta neki a rendi irományokat, 1452-53 fordulóján ugyanis Itáliában járt és Firenzében is megfordult. ${ }^{14} 1453$ februárjában meghalt René felesége, Izabella. Marcello kondoleáló levelét újabb könyvküldemény kísérte. Ezúttal Aranyszájú Szent János egy vigasztaló prédikációjának görög szövegét és latin fordítását küldte el. Az ajánlólevélben ismét elpanaszolja, hogy a távolság és hazája iránti súlyos kötelességei miatt továbbra sincs lehetősége a személyes találkozásra. ${ }^{15}$ Közben juthatott hozzá a rendi irományokhoz, ezt újabb könyvküldemény tanúsítja. Az elegáns, kisméretü, illusztrált pergamenkódex többek között a Holdsarlórend patrónusának egy elbeszélés-változatát tartalmazza. Az ajánlólevélben, amely 1453. június elsején kelt a táborból, és amelyet a „senatori et reliquis fratribus Crescentis Ordinis” intézett, kiderül, hogy ez a „testimonium”, amelyet már mint a rend egy teljes jogú tagja küld el maga helyett. Ezt azért teheti, mert „a magnifico fratre nostro Jo. Cossa” megkapta a „Ceremonias, exhortationes et constitutiones celeberrimi consortii nostri”. Vannak, akik az illusztrációk közül Szent Móric egész alakos képét Mantegnának vagy társának tulajdonítják. Giovanni Bellinitöl származtatják a sokalakos jelenetet. Ugyancsak őt tartják a rend közgyülését megjelenítő kép alkotójának is. Ezen a résztvevő tagok láthatók holdsarlóval ékesített köpenyben és nagyszélü, fekete bársonykalapban. A háttérben a patrónus alakja látható. Az ábrázolás pontosan megfelel a statútumokban leírtaknak, tehát Marcello már ezt ismerve adott megbízást a festőnek. A kötetben Marcello a saját fél alakos profilképét is megörökíttette a Holdsarlórend jelvényét viselve. A kép alapzatán titkosírásos fölirat van, amely föloldva így hangzik: „SE MIA SPERANZA NON DIXE BUGIA | NON FARAI INGRATA PATRIA COSSA MIA”. A következő oldalon a Velencei Köztársaság mint „Serenissima” allegorikus alakja látható. Ez a kép értelmezi az előző oldalon lévő föliratot, amely - magyar fordításban - így szól: „Ha reményem nem csal meg engem,

Huszti, Janus..., Anjou René, i. m., 23. Michael T. Reynolds, René d'Anjou, King of Sicily and the Order of the Croissant, Journal of Medieval History, XIX(1993), 125-161 szerint a rendalapítás is ezt a célt szolgálta.

${ }^{14}$ Francesco Petrucci, Giovanni Cossa = Dizionario Biografico degli Italiani, XXX, Roma, 1984, 89-93

${ }^{15}$ Roma, Biblioteca Apostolica Vaticana, Vat. Lat. 5145. alapján közli az ajánlólevelet MERCATI, i. m., 84-85. Az elegáns kis kódexröl, amelynek díszítése nem készült el, föltételezi, hogy ez a Renének szánt példány. Dominique ThIÉBAUT, Les manuscrits italiens du roi René = Splendeur..., i. $m$, 47. és 52. n. 5. szerint a kézirat nem jutott el Renéhez. 
Cossa nem hoz bajt az én hazámra". ${ }^{16}$ Az üzenet Cossának szólt, de hogyan értsük?

Időközben Itália belháborújába René sógora, VII. Károly francia király is belépett. Előbb csak óvatosan, Milánót támogatva ígért segítséget a Velencével ellenséges viszonyba lévő Firenzének. 1453-ban, sürgetésre, már kilátásba helyezte, hogy júniusban Renét küldi a francia csapatokkal. Velence ezt megpróbálta elhárítani, és René sem nagyon igyekezett. Júniusban, mindenre fölkészülve, elkészítette végrendeletét. Az ősz folyamán átkelt az Alpokon, és októberben végre megérkezett Itáliába. Megtörtént végre a találkozás, amit a két holdsarló-lovag korábban olyan nagyon szeretett volna, ha nem is így, a csatatéren. René és kíséretében Cossa, a lovagiasság szabályai szerint, hírnökükkel átküldte Marcellónak a vaskesztyüt és a rend statútumának megfelelő üzenetet: ,juste ergo movemur ut arma in Italiam feramus." Marcello, mivel ő csak provveditore volt, a Szenátushoz továbbította a küldeményt. Ezután az igazságos háború megindult, és kezdetben a francia csapatokkal megerösített Milánó ért el sikereket. Történt mindez akkor, amikor Konstantinápoly elestének híre már bejárta Itáliát. V. Miklós pápa komoly és eredménytelen lépéseket tett a béke megteremtésére. Végül is beállt a tél, és a seregek visszavonultak. A veszélyeztetett Velence közben titkos tárgyalásokat folytatott Milánóval, ami természetesen kitudódott. Erre az egyébként úgysem túlságosan hadakozó kedvű René 1454. január 3-án elhagyta Itáliát. ${ }^{17}$

Marcello és René között személyes találkozásra, tudtunkkal ezután sem került sor. Kapcsolatukról továbbra is a velenceitől kapott ajándékok tanúskodnak. 1457. márciusában Monselicéből, Padova melletti birtokáról küld neki egy mappamondót, amit ő házi humanistájától, Palla Strozzitól kapott, egy szférát „káldeus” föliratokkal és a Szentföld leírását térképpel. Ezek csak kísérői voltak egy padovai scriptor és illuminátor díszítette, latinra fordított Ptolemaiosznak. ${ }^{18}$

Barátságuk legismertebb emléke a Guarino-fordította Sztrabón egy díszes példánya. Marcello az ajánlást Velencében írta 1459 szeptemberében. Megemlíti, hogy a „hostilitas officialis” 1453-54-ben nem változtatott kölcsönös érzelmei-

${ }^{16}$ Paris, Bibliothèque de l'Arsenal, ms. 940. Passio Mauricii et sotiorum eius $=$ Splendeur..., $i$. m., No. 4, 218-223. (Dominique ThiéBAut) Az ajánlást közli Szentmártoni Szabó Géza, Janus Pannonius, Laudatio Sancti Mauritii et sociorum eius, Bp., 2010 (kézirat). A 100 soros Szent Móricról, a 61. sortól pedig Renére írt Laudatiót aligha az ókori szerzők formulakincsétől soha megszabadulni nem tudó Janus írta. Még akkor sem, ha itt-ott az ő versfordulataival találkozunk. Valószínübbnek tartom, hogy egy prózai szöveg latin versbe öntéséröl van szó. Leginkább Marcello fogalmazványára és Janus fordítói tollára gondolhatunk. Janus már korábban is tett ilyen szolgálatot, amikor Marcello szerelmes verseinek latin tolmácsa volt. Talán ezért nem is szerepel szerző neve a kéziratban.

${ }^{17}$ KING, i. m., 283-290.

${ }^{18}$ Paris, Bibliothèque National, cod. lat. 17542. = Splendeur..., i. m., No. 5., 224-229. (Dominique ThiÉBAUT) Nem tudom, hogy milyen forrás alapján teszi meg ekkor Marcellót Padova podestájává. 1442-ben is csak jelölték erre. 
ken. A szavaknál is többet mondanak a Giovanni Bellininek tulajdonított nagyméretü illusztrációk. Marcello a trón előtt térdepelve nyújtja át Renének a kéziratot. A kép párdarabja azt a jelenetet ábrázolja, amikor Guarino Veronese nyújtja át fordítását pártfogójának, Marcellónak. A képek minden eleme a valóságot tükrözi, vagy jelentést hordoz. Guarino sudár, ősz alakja mögött a kapu diadalívet képez. Az átvevő korosodó, de még mindig jó tartású Marcello hajába ősz szálak keverednek. Ilyennek írta le őt ekkor Janus Pannonius is:

... mind mutogatnak a délceg alakra, szerte ahol jár, s méltóságát még gyarapítja néhány ösz hajszál a sötét fürtök sürüjében.

(Kerényi Grácia fordítása)

A térdeplős képen ugyanezt az idősödő Marcellót látjuk, amint már-már túlzott alázattal nyújtja át a könyvet a karcsú és ifjú Renének. A velencei müvész Guarinót is, Marcellót is jól ismerte, az élőket mintázta. René ugyan csak mintegy tíz évvel volt fiatalabb Marcellónál, mégis ennek útmutatásával ideálképet festett az ekkorra - a korabeli ábrázolások szerint - testesedő, korosodó férfiról. ${ }^{19}$ A Guarinót ábrázoló képen a diadalív centrális elhelyezése a szellemi teljesítmény elismerését jeleníti meg. Párdarabján, a Marcello-René-jeleneten ugyanígy kap helyet az égbe nyúló pálma. A hivatkozás félreérthetetlen, Horatius legismertebb, Maecenashoz írott versére utal:

... palmaque nobilis

terrarum dominos evehit ad deos.

(Horatius I 1, 5-6.)

A háttérben valószínüleg Nápoly idealizált képe látható. A Holdsarlórendre utal a Marcello mögött álló, René kíséretéhez tartozó alak, kezében a rend viseletéhez tartozó nagyszélü, fekete bársonykalap.

Különösen érdemes figyelmünkre a René trónját díszítő basrelief. Egy mogorva, fölséges oroszlánt ábrázol az előtte porig alázkodó nyúllal. A fölirat: „CLEMENTIAE AUGUSTAE”. A képet minden kortárs értette. A leo magnanimus irgalma az elötte megalázkodó iránt Plinius óta közhelyszerủen ismert.

A képhez általában vers is járult, amely két változatban is fönnmaradt:

Parcere prostratis scit nobilis ira leonis.

Tu quoque fac simile quisquis dominaris in orbe.

${ }^{19}$ Albi, Bibliothèque Municipale, ms. 77. = Splendeur..., i. m., No. 6., 226-229. (Dominique ThiÉBAUt) Janus PannoniUs, Panegyricus ad... Marcellum, i. m., 168-169. 
Más változata a római Capitolium kapuját díszítette a képpel együtt, hogy a belépő bírákat figyelmeztesse a hatalmuk adta lehetőségre, a könyörületre:

\section{Iratus recole quod nobilis ira leonis in sibi prostratis se negat esse feram.}

Vers és kép, együtt vagy külön, az egész középkoron át népszerü volt. ${ }^{20}$ A padovai Palazzo della Ragione falát díszítette éppen a Tribunale del leone oroszlánábrázolása alatt a vers első változata. ${ }^{21}$ Ezt Marcello is sokszor láthatta. Bátyja padovai püspök volt, őt magát is jelölték a város podestájának. Első felesége is padovai patríciuslány volt. René trónjának reliefjén a kegyelmet kérő és kegyelmet adó ábrázolásának ritmusa pontosan ismétli a főalakok helyzetét. Minden szónál beszédesebb, hogy miképpen maradt meg Marcellóban örökre a „hostilitas officialis”-ból, valójában a hazája iránti hüségből adódó, de lovagi becsületébe ütköző helyzet emléke.

Valamiképpen Janus is szembekerült a problémával az 1455 és 1458 között írt, Marcello tetteit megörökítő mủvében. René itt háromszor szerepel. Kétszer éppen hogy megemlíti fölbukkanását a történet során, a harmadik az eddig tárgyalt rész, a Holdsarlórend-kitüntetésről..$^{22}$ A tapintat nyilvánvaló, mert ő azután igazán többet tudhatott ennél kettejük kapcsolatáról.

Marcello második kitüntetéséról azt olvassuk Janusnál, hogy annak adományozója a francia király volt: ,post hunc Francorum summa potestas”. Ennek nem sikerült nyomára bukkanni. VII. Károlyról éppen az maradt fönn, hogy - apjával ellentétben - nem ajándékozott rendjeleket. Mivel Janus tanúsítja, el kell fogadnunk, hogy Marcello kapott valamilyen francia kitüntetést. Ez csak 1452 januárja előtt történhetett, mielőtt a király szövetségre lépett a Velence elleni ligával.

A harmadik kitüntetéssel, a „superbae Pannoniae rector"-ától kapottal foglalkozik Janus a legrészletesebben. Magyar fordítása már a bevezetőben olvasható, itt csak a latin szövegre figyelünk:

Quin et Pannoniae rector, tua cura, superbae nobile nuper ei veterum gestamen avorum contulit adveniens, unde illi in pectore laevo igneo gemmati dependet spira draconis.

${ }^{20}$ Robert FAVREAU, Le thème iconographique du lion dans les inscriptions médiévales, Compterendus des séances de l'Académie des Inscriptions et Belles-Lettres, 135(1991), 613-625.

${ }^{21}$ Palazzo della Ragione in Padova, A cura di Pier Luigi Fantelli-Franca Pellegrini, Padova, 1990, 48.

${ }^{22}$ Panegyricus ad... Marcellum, i. m., 1342-1344, 1644-1645, 2650-2655. 
Hegedűs István, a mű első magyarítója a rectort kormányzónak fordította, és jegyzetben hozzáfúzte, hogy „Hunyadi Jánosról van szó”. Ez az értelmezés máig meg is maradt. ${ }^{23}$ Ezzel szemben a „Pannoniae superbae rector”, aki ,adveniens”, itt vagy a német-római császári koronáért Rómába utazó III. Frigyes, vagy a vele hurcolt, megkoronázott magyar király, V. László. Ök jöttek 1452 januárjában Itáliába, amint ezt a bevezetőben már megtárgyaltuk. Az egykorú források elbeszélik, hogy az egyébként fukar uralkodó itáliai útja során szórta maga körül a kitüntetéseket. A szöveget eddig értelmezőket megzavarta a közbevetett „tua cura” kifejezés. Ezt csak úgy értelmezhetjük, hogy a történetet eddig elbeszélő Pallas Athéné itt hirtelen kiszól főhőséhez. Amint korábban láttuk, az „adveniens” uralkodót Marcello figyelmeztette arra, hogy mit vár tőle a meggyötört Itália. Marcello szócsöve akkor a Pro pacanda Italia szerzője, Janus volt. Tovább vihetjük így a gondolatot, éppen Janus lehet az, aki emlékezteti főhősét hajdani fontos szerepére.

Hogy az érkező két király közül Janus itt melyikre gondolt, annak eldöntése bonyolultabb, mint gondolnánk. Frigyes kancelláriája megőrizte az éppen ekkor a Sárkányrend másnak adományozott oklevelének szövegét, mint egy mintaformulát. Idézzük:

„... Praeterea invitat nos affectus integerrime caritatis quem ad serenissimum principem Ladislaum Ungarie Bohemieque regem et patruelem nostrum carissimum gerere dinosceris ut personam tuam specialis amoris insignis decoremus, quare tibi prefato $\mathrm{n}$. predicti patruelis nostri societatis insignia videlicet draconem cum cruce per transversum in dorso ad modum radiorum solarium dispersam concessimus ubique deferendum ad honorem specialem tue persone et societatis patruelis predicti, servatis tamen statutis in capitulis predicte societatis per quondam serenissimum Sigismundum R. imp. ... editis." ${ }^{24}$

Az ajándékozó okmány szerint a megajándékozottnak László magyar és cseh király előtt szerzett érdemeiért, Frigyes, akinek a király atyjafia, ezen, atyjafiának tulajdonát képező Sárkányrendet adományozza. Leírja a jelvényt is: a sárkány, hátán átverve kereszttel, sürün beszórva lángsugarakkal. Viselését pedig a hajdani Zsigmond király statútumai szabályozzák. Frigyes itt a gyám

${ }^{23}$ HegedÜs István, Dicsének Jacobus Antonius Marcellusra, Bp., 1897 (Értekezések a Nyelv- és Széptudományok köréböl, XVI/10), 29, 83.

Söt a te drága hazád feje, kormányzója is egy szép

Ösmüvü boglárt küld, amelyet maga horda a mellén

Ösi vitézkötés, amelyen csupa ékkövü kígyó

Lángszín testével halkal tekerödzeni látszék.

SZÖRÉNYI László, Harmóniára teremtve: Tanulmányok Mátyás királyról, Bp., 2009, 25-26;

SZENTMÁRTONi SzABÓ Géza, Parthenope veszedelme..., i. m., 7.

24 Joseph Chmel, Regesta chronologica-diplomatica Friderici IV. Romanorum regis, 2. Abt., Wien, 1840, No. 2868. 
szerepében jár el, a kiskorú király helyett. Így kellett tennie, mert Zsigmond az alapításkor úgy rendelkezett, hogy utódai a koronázás alkalmával a Sárkányrend jelvényét is kapják meg, és mint tulajdonukkal rendelkezzenek a továbbadásban. ${ }^{25}$ Magyarország megkoronázott királya 1440. május 15-től V. László volt. A büszke Pannonia rectora cím Janusnál elsősorban rá vonatkozhat. Ezt igazolja a „nobile veterum gestamen” is. A királynak nagyapja volt Zsigmond, aki nem csak alapítója, de valóban a sírig viselője volt a Sárkányrendnek. ${ }^{26}$

A korábbi rendjelvények adományozását, amint láttuk, Janus csak röviden fölsorolta, de a Sárkányrendnél hosszasabban időzött. Megtudjuk például, hogy Marcello a jelvényt a bal oldalán viselte. Ez egy tekeredő kígyó volt, amelyet tüzszínü ékkő díszített. ${ }^{27}$ Janus bejáratos volt Marcello otthonába, ezt tanúsítja höse viselt dolgainak legapróbb részletekre is kiterjedő ismerete. A Sárkányrendről írt négy sora tanúsítja, hogy talán az ajánlólevelet is, de a jelvényt mindenképpen látta birtokosán. Hogy a többi jelvénynél nagyobb figyelmet fordított a hazaira, arra egyébként nem kell magyarázatot adnunk. Az már elgondolkoztató, hogy a Marcellóval foglalkozó igen gazdag írásos anyagban sem a francia, sem a Sárkányrend jelvényére nem találunk utalást. Egyetlen talán az utóbbival kapcsolatba hozható ábrázolás a Holdsarlórend tagjainak címereit tartalmazó kódexben található. Csak leírásból tudom, hogy ott Sforza címerállata a „guivre”, a sárkánykígyó, Marcellóé pedig a „dragon”, a sárkány. ${ }^{28}$ A velencei Marcellók korábban címerállatul az ágaskodó oroszlánt viselték.

A Holdsarlórend jelvényéhez a család később is ragaszkodott. Marcello fia monselicei palotájuk átépítésekor ezt a címert is visszarakatta. Az utódok pedig végső nyughelyén, a San Cristoforo della Pacéban, a később megújított epitáfiumra fölvésették René nevét ,cuius et sacrae societati inter primos adscriptus est”. ${ }^{29}$

A 15. század közepén már valóságos divatja volt a rendjelvények összegyüjtésének. Erről képi ábrázolások, sírkövek és hagyatéki leltárak egyaránt tanúskodnak. Kovács Éva szerint: „Bizonyos rendek jelvényéből - a Sárkányrendből bizonyosan - az idők során kitüntetés lett." ${ }^{30}$ Valóban Janus is „insignia”-t írt „ordo” helyett. Mégis lehettek kivételek, így Jacopo Antonio Marcello, akinek a Holdsarlórendhez tartozás egész életére magatartásformát jelentett.

\footnotetext{
${ }^{25}$ BARANYAi Béla, Zsigmond király u. n. Sárkány-rendje, Száz, 59-60(1925-1926), 580.

${ }^{26}$ KovÁCs, i. m., 135.

${ }^{27}$ Uö, A gótikus ronde-bosse zománc a budai udvarban, Müvészettörténeti Értesítő, 31(1982), 92. Az ékkövekkel díszített rendjelvényekröl: LöVEI Pál, A Sárkányrend..., i. m., 154, 155, 159 említ ékkövekkel díszített jelvényeket.

${ }^{28}$ Armorial de l'Ordre du Croissant, Paris, Bibliothèque National, ms. fr. 25204. F. 54v. = Splendeur..., i. m., No. 11., 241.

${ }^{29}$ KING, i. m., 225.

${ }^{30}$ KovÁCs, i. m., 138; LÖVEI, i. m., passim.
} 